Next Steps for the Idle No More Movement: A Public Law Perspective

\author{
Alexander Hudson \\ Department of Government, University of Texas at Austin
}

aboriginal policy studies Vol. 3, no. 1\&2, 2014, pp. 149-163

This article can be found at:

http://ejournals.library.ualberta.ca/index.php/aps/article/view/20810

ISSN: $1923-3299$

Article DOI: http://dx.doi.org/10.5663/aps.v3i1-2.20810

aboriginal policy studies is an online, peer-reviewed and multidisciplinary journal that publishes original, scholarly, and policy-relevant research on issues relevant to Métis, non-status Indians and urban Aboriginal people in Canada. For more information, please contact us at apsjournal@ualberta.ca or visit our website at www.ualberta.ca/nativestudies/aps/.

UNIVERSITY OF ALBERTA

FACULTY OF NATIVE STUDIES
Aboriginal Affairs and

Northern Development Canada

Affaires autochtones et Développement du Nord Canada 


\title{
Next Steps for the Idle No More Movement: A Public Law Perspective
}

\author{
Alexander Hudson \\ Department of Government, University of Texas at Austin
}

\section{Introduction: \#idlenomore}

Since late November 2012, a new movement has been mobilizing Aboriginal rights claims in Canada. The movement, which started with a series of Twitter posts using the hashtag \#idlenomore, has engaged First Nations peoples across the country through social media, teach-ins, and protests (Press and Woods 2013). The rapid growth of the Idle No More movement can be traced back to the social media campaign undertaken by its founders, even though those founders have not exercised any control over this very loosely organized movement (Taylor-Vaisey 2013), and it now exists alongside more traditional groups for Aboriginal mobilization, such as the Assembly of First Nations (AFN) and the Congress of Aboriginal People (CAP). Much like the Occupy movement, Idle No More has grown organically, without central leadership; unlike Occupy, Idle No More has produced a concise list of clearly defined and reasonable statements of grievance (Gordon 2013a). Although it is impossible to say how widely these statements are accepted due to the dispersed nature of the group, the Idle No More movement is notable, on the whole, as one of the most significant political mobilization campaigns on the part of Canada's First Nations in modern history.

One of the most watched events so far in this ongoing campaign was a "hunger strike" undertaken by Chief Theresa Spence of the Attawapiskat First Nation in northern Ontario. In what she now calls a spiritual fast, Chief Spence camped for forty-four days (in the middle of the 2012-2013 Canadian winter) on an island in the Ottawa River, within sight of the Supreme Court of Canada and Parliament Hill, subsisting on fish broth and medicinal tea (Stone 2013). Chief Spence's primary demand during this time was a meeting with both Prime Minister Harper and Governor General David Johnston. When Prime Minster Harper finally agreed to sit down with Chief Spence, she backed out of the meeting when she learned that the governor general would not be there (although she did attend a ceremonial meeting between the governor general and a number of chiefs later that day). Afterwards, Spence continued to refuse to meet with the prime minister unless the governor general was also in attendance, which was a rather extreme position to take. Chief Spence had at that time been on her "hunger strike" for one month, and decided to continue this protest until her demands were met.

The demand that the governor general be involved in the meeting between Aboriginal leaders and the government seems, at first glance, like a very strange request. The governor general certainly has powers, but they are most often seen as being ceremonial in nature. 
It has been very rare in the post-1867 era for the governor general to exercise real political power. On the surface, Chief Spence's actions seem like a political stunt-an attempt to gain attention. However, in the historical context of First Nations treaty law, it is possible to think that Spence had a valid claim to negotiate with the Crown.

This commentary uses Chief Spence's demand to negotiate with the representative of the Crown to motivate a discussion of the ongoing legal and political struggle for Aboriginal rights in Canada. Further, it reviews the developments in Aboriginal rights since the patriation of the Canadian constitution, and the passage of the Charter of Rights and Freedoms, in 1982. In this context, we will be able to analyze the Idle No More movement from the perspective of public law. The central finding of this analysis is that First Nations groups, as a small minority of the overall Canadian population, have been much better served through rights litigation than through majoritarian politics.

\section{The Role of the Crown in Contemporary Aboriginal Rights}

The disappointingly short answer to the question of whether or not Chief Spence was making a reasonable claim in demanding a meeting with both the prime minister and the governor general is "No." In fact, the Prime Minister handled the situation quite well in offering a ceremonial meeting with the governor general but refusing to allow a joint meeting with Aboriginal leaders (Macfarlane 2013). Refusing the meeting preserved the appropriate separation between the representative of the Crown, as the embodiment of executive power, and the elected government. Chief Spence's motivations, and those of other Aboriginal leaders in taking their claims to the Crown are, however, understandable. Many Aboriginal rights claims are based on provisions in treaties and other agreements that were initially negotiated between First Nations and the British Crown. In Canada, for example, while all land not in private ownership is considered Crown Land, ${ }^{1}$ Aboriginal groups point to a 1763 Royal Proclamation as evidence that all land not specifically dealt with through a treaty remains in the hands of First Nations (Erasmus and Sanders 1992, 6, 9). ${ }^{2}$

Additionally, since the majority of the treaties governing the relationship between the Canadian government and First Nations were signed by representatives of the British Crown, there is some intuitive sense in taking complaints about the enforcement of these treaties to the party that originally signed the treaty. The courts have also recognized a special relationship between the Crown and Aboriginal peoples, particularly as manifest in the fiduciary responsibility that the Crown maintains with the First Nations. ${ }^{3}$ Concerning this special relationship between First Nations and the Crown, one scholar has noted, "The obligations under these treaties have been assumed by the Canadian authorities, but in

1 Eighty-nine percent of Canada's land mass is considered Crown land, and is held by the federal or provincial governments.

2 Note that existing reservations are also counted as Crown land.

3 This precedent was set in Guerin v. The Queen, [1985] 13 D.L.R. (4th) 321. 
such a way that the Crown remains symbolically central to the relationship" (Cox 2003). This symbolic significance no doubt informed Chief Spence's claim. It is clear from Chief Spence's statements that she wanted to consult the governor general in his role as personal representative of Her Majesty Queen Elizabeth in Canada (McCullough 2013). ${ }^{4}$ Many would argue that the importance of this relationship is solely symbolic, and has no real purchase in modern Canadian law.

In contemporary Canadian government, the governor general truly is without practical power. The governor general has a fair degree of de jure power-after all, the office is technically the executive-but under Canada's constitutional conventions, the governor general only acts as directed by the prime minister (Russell 2004, 15). As Emmett McFarlane put it: "The governor general plays no political or policy role. He has no autonomous capacity to act in First Nations' interest. Nor does the Queen, for that matter, and if she tried, it would rightly be regarded as an affront to Canadian constitutionalism" (Macfarlane 2013) Furthermore, the current monarch has shown no interest in intervening in the affairs of commonwealth states in any way. For example, the leader of the Green Party of Canada recently sent a request for an investigation into the conduct of the 2011 election directly to the Queen. Her Majesty's press office responded eight months later with a polite refusal to intervene (Hannay 2013). The delay suggests a desire to communicate the impropriety of the request.

Appeals to the Crown are further complicated by the divisibility of the Crown. As a symbolic and legal device, the Crown exists in Right of the United Kingdom, in Right of Canada, and in Right of each of the provinces (Isaac 1994, 225). In Canada, consequently, there are eleven Crowns, which makes an appeal to the Crown in many senses no more useful in practical terms than dealing directly with the federal and provincial governments. This divisibility of the Crown serves to further emphasize the fact that the Crown exists in Canadian government primarily as a symbol, and not as a political actor. This concept of the Crown is complicated further by the fact that the federal and provincial governments exercise the powers of the Crown, and are in this sense indistinguishable from the Crown.

The issue of appeal to the British Crown-the action attempted by Chief Spence in demanding a meeting with Her Majesty's representative in Canada-has actually already been addressed in court. At the time of the patriation of the Canadian constitution in 1982, Aboriginal associations representing bands in Alberta, New Brunswick, and Nova Scotia brought a suit in a United Kingdom Court of Appeals attempting to block the passage of the Canada Act, 1982 in the British Parliament. In the case R. v. Secretary of State for Foreign and Commonwealth Affairs Ex parte Indian Association of Alberta, the court held that, on the basis of the divisibility of the Crown, the obligations of the British Crown in enforcing treaties were delegated to the Crown in Right of Canada, or provinces of Canada, at the time of the passage of the Statute of Westminster, $1931,{ }^{5}$ if not at the time of Confederation

4 McCullough's article also notes that Chief Spence has a history of writing letters to the monarch directly.

5 The Statute of Westminster, 1931 made all Commonwealth parliaments equal with the United Kingdom parliament. This made the Commonwealth states legislatively independent. 
in $1867 .{ }^{6}$ The court further noted that any claims on the basis of treaties between First Nations and the Crown should be made in the courts of Canada, and refused to allow an appeal to the United Kingdom's House of Lords.

While the British Crown signed the majority of the legal documents that establish the relationship between First Nations and the Government of Canada, these agreements are no longer binding on the Crown in Right of the United Kingdom and have been effectively passed on to the Government of Canada. On these grounds then, an appeal to negotiate with the Crown is both politically and legally futile. In the case of Chief Spence's demands, such a request could be an expression of frustration with the failures of the Canadian political system (especially the Conservative Harper government's recent failure to fulfill its duty to consult Aboriginal groups about legislation affecting them), or it could be a political ploy. ${ }^{7}$ In either case such tactics are unlikely to be successful. Chief Spence would have been much better served by accepting the meeting with the prime minister, and arguing her case there. While the Harper government is not likely to be very sympathetic to the needs of its Aboriginal population, the prime minister at least has the capacity to act, whereas the governor general does not. However, there are other avenues of action open to Aboriginal groups. As we will see, Aboriginal groups have also had some success in dealing with the federal government through the courts.

\section{Development of Aboriginal Rights, 1982-Present}

\section{The Constitution Act, 1982}

Appealing to the Crown is certainly not the only way that the Idle No More movement could try to achieve gains for Aboriginal rights, and-more immediately-to address deficiencies in the provision of services on reservations. A better path towards the redress of grievances may be through the courts. In disputes between Aboriginal groups and the government, the letter of the law has often been on the side of the Aboriginals, even if the courts have not ruled that way through much of Canada's history (Slattery 1984).

To better understand Aboriginal rights in contemporary Canada, we should look at how Aboriginal rights have developed in the period following the patriation of the Constitution,

6 R. v. Secretary of State for Foreign and Commonwealth Affairs; Ex parte Indian Association of Alberta, [1982] Q.B. 892 (C.A.).

7 The duty to consult was established by the Supreme Court of Canada in Delgamuukw v. British Columbia (1991) 79 D.L.R. $\left(4^{\text {th }}\right)$ 185, [1991] 3 W.W.R. 97 (B.C.S.C.), rev'd (1993), 104 D.L.R. (4 $\left.{ }^{\text {th }}\right) 470$ (B.C.C.A.). Other significant cases establishing this duty include: R. v. Sparrow, [1990] 1 S.C.R. 1075, 70 D.L.R. (4 ${ }^{\text {th }}$ ) 385; Haida Nation v. British Columbia (Minister of Forests) 2004 SCC 73, [2004] 3 S.C.R. 511; Taku River Tlingit First Nation v. British Columbia (Project Assessment Director) 2003 SCC 74, [2004] 3 S.C.R. 550; Mikisew Cree First Nation v. Canada (Minister of Canadian Heritage) 2005 SCC 69, [2005] 3 S.C.R. 388. See also Dwight G. Newman (2009) The Duty to Consult: New Relationships with Aboriginal Peoples, (Saskatoon: Purich Publishing). The duty to consult comes up in reference to a number of provisions of the omnibus budget bill, Bill C-45 (now known at the Jobs and Growth Act, 2012), which (at 457 pages long) made changes to such laws as the Indian Act, the Navigable Waters Protection Act, and the Environmental Assessment Act. 
and the enactment of the Charter of Rights and Freedoms in 1982. The patriation of the Constitution was a big moment for Canadians, and no less so for the First Nations of Canada. Former Grand Chief of the Assembly of First Nations Matthew Coon Come wrote:

We believed in 1982 that we had turned a corner in our relations with the Canadian Crown, away from the colonial dominance inherent in section 91(24) of the British North America Act and the Indian Act, towards recognition of our Aboriginal status and rights, and towards reconciliation of our contending sovereignties (Coon Come 2002, 70).

The promise of the new constitution was ultimately not fulfilled through government policy, but Aboriginal groups did achieve positive outcomes to some degree in the courts, through mechanisms created by the Constitution Act, 1982.

In addition to constitutionalizing general recognition of Aboriginal and treaty rights, the Constitution Act, 1982 further required the government convene a constitutional conference to define and describe the rights of Aboriginal peoples. This 1983 conference resulted in the first new amendment to the Constitution since patriation, adding land claims recognition and gender equality to the previous recognition of Aboriginal rights. Additionally, the government committed to hold a conference with Aboriginal leaders before making any amendments to the parts of the Constitution that dealt with Aboriginal rights (Russell 2004, 130-31). Many Aboriginal leaders had hoped for more from this conference, particularly with regard to the definition of specific rights. However, the Supreme Court of Canada made up for this legislative shortcoming through its subsequent rulings, which have clarified and entrenched the relevant provisions, found in s. 35(1) of the Constitution Act, 1982. ${ }^{8}$

In the broader Canadian context, passage of the Constitution Act, 1982 fundamentally altered the role of the Supreme Court as an arbiter of rights. The attendant Charter of Rights and Freedoms ushered Canada into the "new constitutionalism," putting the Court at the center of any dispute about rights, and significantly altering the Court's agenda (Hirschl 2004, 103). This had significant effects on Aboriginal rights litigation. In addition to the changes wrought by the Charter of Rights and Freedoms, Part II of the Constitution Act, 1982 specifically dealt with the recognition of the rights of Aboriginal peoples. The impact of this relatively short passage in the constitution has been quite significant. Prior to the patriation of the constitution, Aboriginal rights were legally recognized, but enforcement was problematic (Mainville 2001, 25). One prominent Aboriginal rights lawyer wrote:

The enactment of the Constitution Act, 1982 changed profoundly the character of all aspects of aboriginal law in Canada, including the law concerning the treaties between aboriginal peoples and the Crown. The bald, unelaborated, and

8 The Constitution Act, 1982, being Schedule B to the Canada Act 1982 (UK), 1982, c 11, s. 35(1) reads: "The existing aboriginal rights of the aboriginal peoples of Canada are hereby recognized and affirmed." This section was amended in March 1983 to add s. 35(3) "For greater certainty, in subsection (1) "treaty rights" includes rights that now exist by way of land claims agreements or may be so acquired." In this case even the attempt at clarification leave much to interpretation of what those rights actually are. 
quite cryptic words of s. 35(1), asserting the recognition and affirmation of the existing aboriginal and treaty rights, words capable in themselves of a range of interpretations, have been understood and explained by the Supreme Court of Canada so as to fundamentally transform those existing rights and the nature of the legal relation between the aboriginal peoples holding the rights and the rest of Canadian society (McCabe 2010, 119).

It should be noted that the successful entrenchment of Aboriginal rights was due in large part to the rulings made by the judiciary. As mentioned in the quotation above, the language in the relevant passage of the Constitution leaves much to interpretation. Reviewing the potential impact of this new passage in the Constitution shortly after the text was made law, Brian Slattery suggested that it would be up the courts to develop principles for applying this constitutionalization of Aboriginal rights (Slattery 1983, 273). Over the past three decades the courts have been active in taking up this challenge.

One of the most significant cases in establishing Aboriginal rights in the era following the patriation of the Constitution was $R$. v. Sparrow..$^{9}$ The case ostensibly dealt with violations of fishing regulations, but the Supreme Court's ruling was the first decision that established the meaning of the vague statements in s. 35(1) of the Constitution. The decision had an impact of Aboriginal rights in several ways. First, the court established that the rights guaranteed by s. 35(1) had to be in existence when the Constitution was adopted, but that these rights would be ruled to exist regardless of the extent to which they had been reduced through regulation (Macklem 2001, 58). Further, the Court recognized that Aboriginal rights include activities that are fundamental to the maintenance of Aboriginal culture, such as subsistence hunting and fishing. Another important signal in the Court's ruling on R. v. Sparrow was its interpretation of the intent of s. 35(1) as being remedial, providing a means for Aboriginal groups to challenge the legacy of mistreatment by the Canadian government (McCabe 2010, 124). ${ }^{10}$ The ruling in R. v. Sparrow, established an important precedent in Canadian jurisprudence for deciding whether a law that infringes Aboriginal rights is constitutional (Reynolds 2005, 98-99). The Sparrow Principles, or Sparrow test, were summarized by the British Columbia Court of Appeal in R. v. Jack, as including two steps: first, the establishment of a prima facie infringement of s. 35(1); and second, an inquiry into whether there is a valid justification for such an infringement (including four questions that determine this validity). ${ }^{11}$ Refined through a number of later cases, judicial application of the Sparrow test has given concrete meaning to the language of s. 35(1), and made it useful in defending Aboriginal and treaty rights. ${ }^{12}$ In this way the Canadian

9 R. v. Sparrow, [1990] 1 S.C.R. 1075, 70 D.L.R. (4 $\left.4^{\text {th }}\right) 385$.

10 McCabe and Timothy $(2010,124)$ The Law of Treaties Between the Crown and Aboriginal Peoples.

11 R. v. Jack [1996] 2 C.N.L.R. 113 (B.C.C.A.) at 115-116.

12 Later cases include: R. v. Badger, [1996] 1 S.C.R. 771, 133 D.L.R. (4 $\left.{ }^{\text {th }}\right) 324$, [1996] 2 C.N.L.R. 77; R. v. Gladstone, [1996] 2 S.C.R. 723, 137 D.L.R. (4 $\left.{ }^{\text {th }}\right)$ 648, [1996] 4 C.N.L.R. 65; and R. v. Adams, [1996] 3 S.C.R. 101, 138 D.L.R. (4 $\left.{ }^{\text {th }}\right) 657$, [1996] 4 C.N.L.R. 1. 
courts have given enforcement powers to the Constitution's vague promise of respect for Aboriginal and treaty rights.

Duty to Consult

A further outlet for Aboriginal mobilization in influencing government policy has come through the government's "duty to consult" Aboriginal groups about laws that affect their territories or way of life. While motivated by the continuing plight of Aboriginals living in poverty on reservations, the Idle No More movement began as an expression of opposition to a specific piece of legislation, known as Bill C- 45 while it was in Parliament, and renamed with the hopeful title of the Jobs and Growth Act, 2012 after receiving royal assent and becoming law. ${ }^{13}$ The bill, referred to as an omnibus budget bill, bundled together a number of pieces of legislation so that they could be passed in one vote in the House of Commons. An omnibus bill is, essentially, a means for the majority party to limit debate and move forward with their legislative agenda quickly. As noted earlier, the provisions included in Bill C-45 made changes to a number of statutes that are important to Aboriginal rights, including the Indian Act, the Navigable Waters Protection Act, and the Environmental Assessment Act. In what seems to be a violation of this duty, the Conservative government did not consult Aboriginal groups about these changes.

The duty to consult is found in both Canadian law and in international agreements to which Canada is a party. The stronger case is found in Canadian law, beginning with the precedent in Delgamuukw v. British Columbia. ${ }^{14}$ The duty on the part of the government to enter into meaningful consultations with First Nations about legislation affecting them was further entrenched with a trio of cases that were decided in the early 2000s (Newman 2009, 12). These cases-Haida Nation v. British Columbia, Taku River Tlingit First Nation v. British Columbia, and Mikisew Cree First Nation v. Canada-all dealt with government approval of commercial enterprises that could have an adverse effect on Aboriginal rights and way of life. ${ }^{15}$ The courts found that federal or provincial governments could not give approval to development projects without first consulting with the First Nations that would be affected. Crucially for the Idle No More movement, this duty to consult is considered to extend also to new legislation that could affect First Nations.

In Haida Nation, the court's opinion specified conditions under which the duty to consult arises. Chief Justice McLachlin wrote:

The foundation of the duty in the Crown's honour and the goal of reconciliation suggest that the duty arises when the Crown has knowledge, real or constructive,

13 Jobs and Growth Act, 2012, SC: 2012, c. 31.

14 Delgamuukw v. British Columbia (1991) 79 D.L.R. (4 $\left.4^{\text {th }}\right)$ 185, [1991] 3 W.W.R. 97 (B.C.S.C.), rev'd (1993), 104 D.L.R. (4 $\left.{ }^{\text {th }}\right) 470$ (B.C.C.A.).

15 Haida Nation v. British Columbia (Minister of Forests) 2004 SCC 73, [2004] 3 S.C.R. 511 [hereafter Haida Nation]; Taku River Tlingit First Nation v. British Columbia (Project Assessment Director) 2003 SCC 74, [2004] 3 S.C.R. 550; Mikisew Cree First Nation v. Canada (Minister of Canadian Heritage) 2005 SCC 69, [2005] 3 S.C.R. 388. 
of the potential existence of the Aboriginal right or title and contemplates conduct that might adversely affect it. Consultation and accommodation before final claims resolution preserve the Aboriginal interest and are an essential corollary to the honourable process of reconciliation that s. 35 of the Constitution Act, 1982, demands. ${ }^{16}$

The legislation passed in the Jobs and Growth Act, 2012 seems to reach the standard for mandatory consultation set in Haida Nation, particularly through its effect in reducing the power of environmental impact assessments-a means through which Aboriginal groups have defended their way of life against the adverse effects of new development in natural resource extraction such as forestry and mining (Galloway 2013). This is a particular concern in areas of Saskatchewan and Alberta, where oil, gas, and mineral exploitation cause environmental concerns for First Nations.

In response to the Jobs and Growth Act, 2012, Aboriginal groups have pursued a legal challenge in a Canadian Federal Court, and filed a complaint at the United Nations. The more significant action is a request filed in a Canadian Federal Court for judicial review of Bill C-45 and an earlier, similar piece of omnibus legislation, Bill C-38, on the grounds that the government violated Aboriginal rights through its failure to consult First Nations about the legislation. ${ }^{17}$ This application for judicial review was filed by two bands from northern Alberta, the Mikisew Cree First Nation and the Frog Lake First Nation. Both bands are located in areas of Alberta where oil sands exploitation takes place. The court has not yet decided this case, but it is unlikely that the court will strike down the legislation. Rather the First Nations bands bringing the complaint hope that the court will order the government to consult with Aboriginal groups about its implementation (MacKinnon 2013). Unlike the system for judicial review in the United States, the Canadian process does require an actual legal case in the normal sense, but individuals whose rights have been infringed by legislation can challenge that legislation in court. ${ }^{18}$ This process is generally less expensive and time consuming than launching a civil suit.

The second legal action related to the duty to consult was a Request for Consideration filed by Chief Spence and the International Indian Treaty Council (IITC) at the UN Committee on the Elimination of Racial Discrimination (CERD). ${ }^{19} \mathrm{~A}$ commitment similar to the duty to consult is found in two UN agreements to which Canada is a party. The UN Declaration of the Rights of Indigenous Peoples requires states to "consult and cooperate

16 Haida Nation, supra note 32 at para. 35.

17 Chief Steve Courtoreille et al. v. The Governor General in Council et al., Federal Court Docket number T-43-13 and the companion case Chief Clifford Stanley et al v. The Governor General in Council et al, Federal Court Docket Number T-44-13.

18 Constitution Act, 1982, being Schedule B to the Canada Act 1982 (UK), 1982, c 11, s. 24.

19 International Indian Treaty Council, letter to UN Committee on the Elimination of Racial Discrimination, Febrary 10, 2013, Accessed May 9, 2013, http://treatycouncil.org/PDF/IITC-Mushkegowuk-UA2013FINAL.pdf. 
in good faith with the indigenous peoples ... in order to obtain their free and informed consent prior to the approval of any project affecting their lands or territories and other resources, particularly in connection with the development, utilization or exploitation of mineral, water, or other resources." ${ }^{20}$ While the language in the Declaration is strong, Canada waited several years before giving the Declaration its support, and is unlikely to consider its sentiments binding. It is also unlikely that the Harper government will pay any attention to a ruling from CERD, but the act of filing the application increased media attention on the conditions in the Attawapiskat First Nation, ${ }^{21}$ the effects of Bills C-38 and C-45, and on the campaign mounted by Chief Spence.

We will have to wait to see how the Federal Court will rule in its judicial review of the Jobs and Growth Act, 2012. The challenges mounted by Mikisew Cree First Nation and the Frog Lake First Nation could set a positive precedent for enforcement of the duty to consult, an area of law that the Canadian Supreme Court has recognized as needing further development in the lower courts (Newman 2009, 23). The doctrine, so far, has been developed in cases dealing with relatively small claims. The statutory changes made by the Jobs and Growth Act, 2012 have effects across the country; enforcement of the duty to consult in these challenges would, therefore, be all the more influential.

\section{Constitutional Amendment and Aboriginal Self-Government}

One of the stated goals of the Idle No More movement is to "help build sovereignty and the resurgence of nationhood" (Gordon 2013b). In terms of broader reforms to the Aboriginal relationship with federal and provincial governments, it is possible that a constitutional amendment might be used to alter the relationship in a way that would give First Nations more autonomy. There are, of course, significant political challenges to this approach. First, Prime Minister Harper recently expressed an extreme aversion to any discussion of changes to the Constitution (Blatchford 2013). Second, it is quite difficult to amend the Canadian Constitution; only ten amendments have been passed since the new amending formula was established in 1982. Notably, the first and only amendment of national importance to have been passed, and thus requiring ratification through the so-called 7/50 formula, dealt with Aboriginal rights (Hueglin 2013, 34). Under the 7/50 formula, amendments that affect more than one province require passage in the House of Commons and the Senate and further approval on the part of at least two-thirds of the provincial legislatures, representing at least $50 \%$ of the population of Canada. These rules set the threshold for approval of significant renegotiation of the relationship between First Nations and the federal and provincial governments very high, but this path also holds the most potential for fundamental change.

20 UN General Assembly, United Nations Declaration on the Rights of Indigenous Peoples: resolution / adopted by the General Assembly, 2 October 2007, A/RES/61/295, Article 32, Accessed May 9, 2013, http:// www.refworld.org/docid/471355a82.html.

21 Conditions at Attawapiskat First Nation's reservation had been the subject of an investigation by a UN Special Rapporteur a year earlier, when the band's inadequate provision of housing reached a crisis situation as winter approached. See Mackrael (2013). 
The most recent of what Peter Russell (2004) refers to as Canada's rounds of "megaconstitution politics" ended with the Charlottetown Accord in 1992. The Accord was the product of a series of broad public consultations about the future of constitutionalism in Canada, and of several lengthy rounds of elite negotiations between the federal government and the provinces. The Charlottetown process was also notable for being one of the first times that representatives of Canada's First Nations were given a seat at the negotiating table $(2004,169)$. The Accord was defeated in a referendum in October 1992, and has no force of law, but it is worth looking at for a moment as an example of the best deal that Aboriginal groups have yet been able to extract from Ottawa and the provinces. Former Grand Chief of the Assembly of First Nations Matthew Coon Come has called it "the all-time high point in Crown-Aboriginal relations in Canadian history" $(2002,70)$.

The most interesting aspect of the Charlottetown Accord as it relates to Aboriginal self-government was the proposed creation of a "third order" of federalism. First Nations have enjoyed some rights to self-government throughout Canadian history, and especially since the 1980s, but the Charlottetown Accord would have gone much further than any previous arrangements (Coates and Morrison 2008, 106). The deal reached by the prime minister, provincial premiers, and Aboriginal representatives would have established separate Aboriginal jurisdiction alongside the current division of law-making authority between the federal and provincial governments (Russell 2004, 201). This would have made First Nations sovereign within certain areas of legislation. It is unclear what this would have meant in practice, but one interpretation is that the proposed creation of Aboriginal federalism would have recognized First Nations sovereignty over a limited sphere of core issues, and overlapping jurisdiction with federal and provincial governments in other areas (Macklem 2001, 180).

Why bring this up again twenty years after the Charlottetown Accord was rejected in a nation-wide referendum? One reason is that the ideas about Aboriginal self-government that were included in the Charlottetown Accord have continued to have currency within academic circles in Canada (Abele and Prince 2006). A second reason is that these proposals were never given a chance to be considered as a reform process in their own right. The referendum only offered a yes/no vote on the whole package of sixty reforms proposed in the Charlottetown Accord. Polling at the time indicated that the majority of Canadians supported Aboriginal self-government (Russell 2004, 131), which suggests that while the whole Charlottetown package was unsuccessful, this part of it might have enough popular support to pass. This public support may not translate into immediate support from the federal and provincial legislatures, but Idle No More activists could look at some of the best parts of the Charlottetown Accord for inspiration about how to move forward with respect to Aboriginal sovereignty.

\section{What Next for Idle No More?}

The Idle No More movement arose in the near term in response to Bills C-38 and $\mathrm{C}-45$, but it is also a manifestation of longer-term struggles for Aboriginal rights, and as a 
response to the deplorable conditions that exist on many reservations. To continue to move forward, Idle No More can respond to these challenges on a number of fronts. The public law orientation in this paper has included considerations of litigation and constitutional amendments as options that the Idle No More movement could pursue in addressing the concerns of Aboriginal Canadians. However, these avenues of action are not likely to address the more pressing concerns of many Aboriginals in the near term, particularly the dire conditions experienced by many Aboriginals living on reservations. Member of Parliament Romeo Saganash, an Aboriginal Canadian, recently commented that decades of litigation and negotiation have not done much to improve the lives of more Aboriginals (Munson 2013). Instead, Saganash proposes that a deeper, ongoing national dialogue between Aboriginals and broader Canadian society is necessary to move the relationship forward. This sounds good, but dialogue might not create change either.

What is clear is, that as 4.3 percent of the Canadian population, Aboriginal groups need support from other Canadians in order to make gains through the regular political process. ${ }^{22}$ Furthermore, data from polls taken at the height of the Idle No More movement in January 2013 shows that the movement should be careful about how it engages with the rest of the country. On the positive side, according to one national poll, 56 percent of Canadians believe that there is an urgent need for change in the policies of the federal government with regard to Aboriginal people (Payton 2013). However, the same poll found that 62.3 percent of Canadians think that the historically favored tactic of Aboriginal protest, blockades of roads and railways, will not help Aboriginal groups achieve their goals (Payton 2013). ${ }^{23}$ A separate poll taken around the same time showed that attitudes toward Aboriginals among non-native Canadians are broadly negative. Surprisingly, at least in light of the conditions on many reservations, the poll found that nearly two-thirds of Canadians think that Aboriginals receive too much money from the federal government (Mahoney 2013). An even more depressing finding from this poll is that 60 percent of Canadians think that the problems faced by Aboriginals are their own fault. This poll also asked about support for the Idle No More movement. At that time the movement was supported by only 38 percent of Canadians, and it is not likely to have gained popularity in the months since that time.

To move forward through the majoritarian democratic process, Idle No More will need to engage with broader Canadian society in more positive ways. Blockades and other such tactics can only reduce support for the movement. Teach-ins and social media so far seem to have reached mostly other Aboriginals. Expanding this outreach could have some positive effects. Additionally, while there is no simple answer, rights-based litigation has provided Aboriginal groups with a number of significant victories since the patriation of

22 Statistics Canada, National Household Survey 2011, "Aboriginal Peoples in Canada: First Nations People, Métis and Inuit," Catalogue no. 99-011-X2011001, Accessed May 12, 2013, http://www12.statcan.gc.ca/ nhs-enm/2011/as-sa/99-011-x/99-011-x2011001-eng.pdf.

23 Ibid. Around the time of this poll, Idle No More protestors had blockaded a number of highways, bridges, and rail lines for short periods of time. 
the Constitution in 1982. Litigation takes time, and often has effects that are limited in scope, but it is one way for a small minority to assert its rights within a democratic society. At this point in time, Idle No More has few viable options. Litigating rights claims and pursuing judicial review of legislation may be the best that Idle No More can do in the near term, short of restarting the constitutional amendment process.

\section{Conclusion}

The effects of rights-based litigation and the constitutionalization of rights claims have been found wanting in a number of studies, and the conventional wisdom in political science circles would suggest that these are not profitable avenues for Idle No More activists to explore. Certainly the litigation successes experienced by First Nations in Canada over the past three decades have not brought about the kinds of social change Gerald Rosenberg looked for in his influential study of the US Supreme Court (Rosenberg 2008). But, at the same time, the constitutionalization of Aboriginal rights in 1982, and the subsequent exercises of judicial review, seem to have had far more positive effects than Ran Hirschl describes in his examination of this topic (Hirschl 2004). From the perspective of public law, there is something of a mixed outlook for Idle No More.

Constitutional amendment could yield significant payoffs. But this is true for any movement. This difference in the case of Idle No More is that the path toward an amendment that could create Aboriginal government as a third order of federalism has already been well trodden-these negotiations took place in 1992. Another point in favor of attempting constitutional amendment is the fact that the only successful national-level amendment to the constitution dealt with Aboriginal rights. Furthermore, at the time of the last attempt at "mega-constitutional" politics, there was widespread support for Aboriginal self-government. Constitutional amendment is only indirectly related to popular opinion, and if Aboriginal groups can make a good case to provincial legislatures about the mutual gains that could be made through greater sovereignty for First Nations, there may be some hope for an amendment.

Though still sub-optimal, legally based approaches to Aboriginal rights mobilization are more appealing when compared to the possibilities for progress through electoral politics. Aboriginal Canadians are a very small minority, and are not highly regarded by the rest of the Canadian population. These are not the conditions that favor success in majoritarian politics. In light of these disadvantages, it seems that they best path forward for Idle No More is through the courts. 


\section{Bibliography}

Abele, F. and M.J. Prince. 2006. "Four Pathways to Aboriginal Self-Government in Canada," American Review of Canadian Studies 36 (4): 568-95. Canada," American Review of Canadian Studies, 36 (4): 568-95. http://dx.doi.org/10.1080/02722010609481408.

Blatchford, A. 2013. "Harper tells Quebec audience he's fed up with constitutional battles." The Globe and Mail, May 3. Accessed May 11, 2013. http://www.theglobeandmail. $\mathrm{com} /$ news/politics/harper-tells-quebec-audience-hes-fed-up-with-constitutionalbattles/article11703042/.

Coates, K.S. and W.R. Morrison. 2008. "From Panacea to Reality: The Practicalities of Canada Aboriginal Self-Government Agreements," In Aboriginal Self-Government in Canada: Current Trends and Issues, edited by Y.D. Belanger, 105-22. Saskatoon: Purich Publishing.

Coon Come, M. 2002. "Charlottetown and Aboriginal Rights: Delayed but Never Relinquished." Policy Options Politiques, December-January, 70-72.

Cox, N. 2003. "The Treaty of Waitangi and the Relationship Between the Crown and Maori in New Zealand." Brooklyn Journal of International Law 28 (1): 1-31.

Erasmus, G. and J. Sanders. 1992. "Canadian History: An Aboriginal Perspective." in Nation to Nation: Aboriginal Sovereignty and the Future of Canada, edited by D. Engelstad and J. Bird, 3-11. Concord, ON: Anansi Press.

Galloway, G. 2013. "First Nations say cuts to environmental oversight violate treaty rights." The Globe and Mail, January 8. Accessed May 9, 2013. http://www.theglobeandmail. $\mathrm{com} /$ news/politics/first-nations-say-cuts-to-environmental-oversight-violatetreaty-rights/article7038171/.

Gordon, J. 2013a. “Manifesto." Idle No More, January 21. Accessed May 7, 2013. http:// idlenomore.ca/manifesto.

___. 2013b. “Vision.” Idle No More, January 21. Accessed May 7, 2013. http://idlenomore. $\mathrm{ca} /$ vision.

Hannay C. 2013. "Elizabeth May asks Queen to investigate robo-calls, Queen declines." The Globe and Mail. April 4. Accessed May 8. http://www.theglobeandmail.com/news/ politics/elizabeth-may-asks-queen-to-investigate-robo-calls-queen-declines/ article10784149/

Hirschl, R. 2004. Towards Juristocracy: The Origins and Consequences of the New Constitutionalism. Cambridge, MA: Harvard University Press.

Hueglin, T.O. 2013. "Comparing Federalism: Variations or Distinct Models." in Federal Dynamics: Continuity, Change, and the Varieties of Federalism, edited by Arthur Benz and Jorg Broschek, 27-47. Oxford and New York: Oxford University Press.

Isaac, T. 1994. "The Concept of the Crown and Aboriginal Self-government." The Canadian Journal of Native Studies 14 (2): 221-50.

Macfarlane, E. 2013. "On the power of the Governor General." Macleans, January 11. Accessed May 7, 2013. http://www2.macleans.ca/2013/01/11/on-idle-no-morethe-governor-general-should-remain-idle/. 
MacKinnon, L. 2013. "Native bands challenge omnibus bill in court." CBC News, January 7. Accessed May 9, 2013. http://www.cbc.ca/news/politics/story/2013/01/07/pol-twobands-duty-to-consult-court-challenge.html.

Macklem, P. 2001. Indigenous Difference and the Constitution of Canada. Toronto: University of Toronto Press.

Mackrael, K. 2013. "UN official blasts 'dire' conditions in Attawapiskat." The Globe and Mail, December 20. Accessed May 9, 2013. http://www.theglobeandmail.com/ news/politics/un-official-blasts-dire-conditions-in-attawapiskat/article4085452/.

Mahoney, J. 2013. "Canadians' attitudes hardening on aboriginal issues: new poll." The Globe and Mail, January 16. Accessed May 12, 2013. http://www.theglobeandmail. $\mathrm{com} / \mathrm{news} /$ national/canadians-attitudes-hardening-on-aboriginal-issues-newpoll/article7408516/.

Mainville, R. 2001. An Overview of Aboriginal and Treaty Rights and Compensation for their Breach. Saskatoon: Purich Publishing.

McCabe, J. and S. Timothy. 2010. The Law of Treaties Between the Crown and Aboriginal Peoples. Dayton, OH: LexisNexis.

McCullough, J.J. 2013. "Media Bites: ChiefSpence, Your 15 Minutes Are Up." Huffington Post, January 10. Accessed May 7, 2013. http://www.huffingtonpost.ca/jj-mccullough/ theresa-spence-bans-media_b_2445493.html?view=print\&comm_ref=false.

Munson, J. 2013. "How will peace come? Taking stock of Idle No More." iPolitics, May 1. Accessed May 12, 2013. http://www.ipolitics.ca/2013/05/01/how-will-peace-cometaking-stock-of-idle-no-more/.

Newman, D.G. 2009. The Duty to Consult: New Relationships with Aboriginal Peoples. Saskatoon: Purich Publishing.

Payton, L. 2013. "Canadians want change on aboriginal policy, poll suggests." $C B C$ News, January 27. Accessed May 12, 2013. http://www.cbc.ca/news/politics/ story/2013/01/25/pol-nanos-first-nations-metis-inuit-poll.html.

Press, J., and M. Woods. 2013. "Ide No More movement 'different' from anything the government had ever seen before, documents reveal." Ottawa Citizen, April 10. Accessed May 7, 2013. http://www.ottawacitizen.com/story_print. html?id=8218741\&sponsor $=$.

Rosenberg, G.N. 2008. The Hollow Hope: Can Courts Bring About Social Change? Chicago: University of Chicago Press.

Russell, P.H. 2004. Constitutional Odyssey: Can Canadians Become a Sovereign People. Toronto: University of Toronto Press.

Slattery, B. 1983. “The Constitutional Guarantee of Aboriginal and Treaty Rights.” Queen's Law Journal 8: 232-73.

- - - 1984. "The Hidden Constitution: Aboriginal Rights in Canada." The American Journal of Comparative Law 32 (2), The New Canadian Constitution: 361-91. http:// dx.doi.org/10.2307/840473. 
Statistics Canada. National Household Survey 2011. "Aboriginal Peoples in Canada: First Nations People, Métis and Inuit." Catalogue no. 99-011-X2011001. Accessed May 12, 2013. http://www12.statcan.gc.ca/nhs-enm/2011/as-sa/99-011-x/99-011x2011001-eng.pdf.

Stone, L. 2013. "Attawapiskat chief Theresa Spence takes more hopeful tone." Global News, April 10. Accessed May 8, 2013. http://globalnews.ca/news/469298/attawapiskatchief-theresa-spence-takes-more-hopeful-tone/.

Taylor-Vaisey, N. 2013. “A rough guide to \#IdleNoMore." Macleans, January 10. Accessed May 7, 2013. http://www2.macleans.ca/2013/01/10/a-rough-guide-to-idlenomore/

UN General Assembly. 1966. International Covenant on Civil and Political Rights, 16 December, United Nations, Treaty Series, vol. 999, p. 171. Accessed May 9, 2013, http://www.refworld.org/docid/3ae6b3aa0.html.

- - - 2007. United Nations Declaration on the Rights of Indigenous Peoples: resolution / adopted by the General Assembly, 2 October 2007, A/RES/61/295, Article 32, Accessed May 9, 2013, http://www.refworld.org/docid/471355a82.html. 